\title{
Adaptation and cross-adaptation of hydrochloric acid and acetic acid mixtures
}

\author{
PAUL G. J. GANZEVLES and JAN H. A. KROEZE \\ University of Utrecht, Utrecht, The Netherlands
}

\begin{abstract}
Adaptation and cross-adaptation of acetic acid, hydrochloric acid $(\mathrm{HCl})$, and mixtures thereof were determined by means of a filter paper method. In the case of $\mathrm{HCl}$, no self-adaptation was observed and adaptation to $\mathrm{HCl}$ had no sourness-decreasing effect in the mixtures. Perceived sourness of the mixtures appeared to be identical to the sourness of the corresponding acetic acid. Self-adaptation of the mixtures was identical to the self-adaptation of acetic acid. After adaptation to distilled water, sourness increased relative to the sourness measured with the unadapted tongue, and in this respect there was no difference between acetic acid sourness and the mixture sourness. No sourness addition of $\mathrm{HCl}$ and acetic acid occurred. These findings suggest at least two different processes by which sourness can be elicited. The difference in self-adaptation between carboxylic acids and nonacidic compounds, as observed in earlier studies, cannot be ex. plained by $\mathrm{H}^{+}$ion activity. For research applications, $\mathrm{HCl}$ and carboxylic acids should not be considered comparable sourness-eliciting agents.
\end{abstract}

Perception of the sourness of acidic compounds has been studied extensively, but the mechanism involved is still not fully understood.

The most obvious property shared by all acids is the dissociation into protons and acid anions when they are dissolved in water:

$$
[\mathrm{HA}] \rightarrow\left[\mathrm{H}^{+}\right] \cdot\left[\mathrm{A}^{-}\right] .
$$

With most acids, the dissociation is not complete and the amount of dissociation that is dependent on the chemical structure is reflected by the equation:

$$
K=\left[\mathrm{H}^{+}\right]\left[\mathrm{A}^{-}\right] /[\mathrm{HA}],
$$

in which $K$ is the dissociation constant. There is, however, no simple relationship between the concentration of free protons $\left(\mathrm{H}^{+}\right)$and the perceived sourness. Aqueous solutions of strong acids (i.e., $K$ is large) taste more sour than weak acids ( $K$ is small) when the molar concentrations are equal. If, however, the $\mathrm{H}^{+}$concentrations are equal, the sourness of the weak acids is higher than that of the strong acids.

This problem was clearly demonstrated by Crouzier (1916) and by Harvey (1920), who compared hydrochloric acid with acetic acid. More recently, this discrepancy was examined by Beidler (1967), Beets (1978), and Norris, Noble, \& Pangborn (1984). Pilnik (1966) reported that acid sourness was more closely related to the concentration of the undissociated acid than to $\mathrm{pH}$. Chauncey, Feller, and Shannon (1967), in their extensive study into the influence of molecular structure on sourness perception, suggested that in almost all cases the hydrogen ion was the principal factor, while the structure of the anion was of secondary importance. Taylor, Farthing, and Ber-

The authors' mailing address is Psychological Laboratory, University of Utrecht, Sorbennelaan 16, 3508 TB Utrecht, The Netherlands. man (1930) and Gardner (1980) suggested that the lipophilicity of the acid anion played an important role in the sourness perception process. Thus, it may be that acid sourness is elicited by the combined effect of $\mathrm{H}^{+}$activity and a physicochemical interaction of the acid anion with receptor sites. The latter process may result in further dissociation of the acid molecules (Makhloaf \& Blum, 1972; Norris et al., 1984). Such a titration process was suggested by Kenrick (1931) and Beatty and Cragg (1935). They showed that the amount of phosphate buffer required to bring the $\mathrm{pH}$ of equimolar solutions of different acids to about 4.5 was proportional to relative sourness.

In line with the postulation of a titration-like process at the receptor, the sourness of buffered carboxylic acids has been found to be about equal to the sourness of the corresponding acid (Beidler, 1967; Pilnik, 1966; Ganzevles \& Kroeze, 1987a, 1987c).

The hypothetical titration process could be effective in two ways: (1) by a two-step reaction in which, first (a) the dissociation of the weak acid is catalyzed, after which (b) sourness is measured via the hydrogen ion in the same way as in the case of strong acids; or (2) by bonding of the undissociated acid in which the functional acid group $(-\mathrm{COOH})$ plays a major role.

In the first case, the hydrogen ion is, exclusively, the sourness-eliciting agent. The sourness differences between weak and strong acids may be due to the amount of dissociation and the rate of the first reaction step (a). In the second case, the hydrogen ion does not play a role at all; that is, the sourness-eliciting processes of strong and weak acids are different.

Aqueous solutions of weak acids, in which the hydrogen ion $\left(\mathrm{H}^{+}\right)$, as well as undissociated acid (HA), is present, can be viewed as a mixture of both agents and their sourness may be a combined effect. If titration-like processes run via the two-step reaction (1), a combina- 
tion of sourness of both agents is self-evident. According to Frijters and Oude Ophuis (1983), a simple addition of sourness from different sources may be assumed only if there is no cross-adaptation between the components.

Ganzevles and Kroeze $(1987 a, 1987 \mathrm{c})$ reported that $\mathrm{HCl}$, in contrast to weak carboxylic acids, does not show self-adaptation and that no cross-adaptation occurs between $\mathrm{HCl}$ and carboxylic acids.

Moskowitz (1974) reported that binary mixtures of $\mathrm{HCl}$ and citric acid taste more sour than predicted by the addition model (synergism). The psychophysical sourness function, however, of a mixture of citric acid and a more related acid (succinic acid) appears to be identical to the predicted function. Curtis, Stevens, and Lawless (1984), using a sip-and-spit procedure, found an addition of sourness at lower concentrations in $\mathrm{HCl}$ and citric acid mixtures. The perceived sourness at higher concentrations of these mixtures was lower than might have been predicted from the combined power functions; that is, only partial addition occurred.

Although not mentioned by Curtis et al. (1984), a problem associated with mixtures of strong and weak acids is the suppression of dissociation of the weak acid by the hydrogen ions of the strong acid. Such mixtures are not simply the sum of their separate components.

In an attempt to investigate the individual contribution to sourness of undissociated acid (HA) and of $\mathrm{H}^{+}$ions, mixtures of $\mathrm{HCl}$ and acetic acid were used in the present study. In these mixtures, the amount of $\mathrm{H}^{+}$ions coming from acetic acid is so small that their contribution can be neglected (Ganzevles \& Kroeze, 1987a). So the sourness of the mixture must result from the combined activity of two different agents from two different sources.

With these binary mixtures, a lower perceived sourness than predicted by the power function cannot be ascribed to suppression of the dissociation of acetic acid by $\mathrm{HCl}$. If sourness perception of $\mathrm{HCl}$ is suppressed by acetic acid, adaptation to acetic acid should lead to diminished suppression. This would be a case of suppression release (Lawless, 1979, 1982).

Ganzevles and Kroeze $(1987 \mathrm{~b}, 1987 \mathrm{c})$ reported that, when measured with a filter paper method, self-adaptation of carboxylic acids is lower than that of nonacidic compounds. The fact that it was also found that $\mathrm{HCl}$ does not show self-adaptation (Ganzevles \& Kroeze, 1987a, 1987c) suggests that the $\mathrm{H}^{+}$ions of the carboxylic acid have a relatively strong effect on $\mathrm{HA}$-adapted tissue. If this hypothesis is correct, self-adaptation of mixtures of $\mathrm{HCl}$ and acetic acid will be lower than that of pure acetic acid.

\section{METHOD}

\section{Subjects}

Ten nonsmoking students ( 8 female, 2 male) served as paid subjects (mean age 21.0, range 19-24). The subjects had no prior experience in taste experiments. Each subject was given an equal amount of training in magnitude estimation (Stevens, 1975). The subjects were naive as to the purpose of the experiment.

\section{Stimuli}

All solutions were prepared with distilled water as solvent and reagent grade chemicals as solutes. The stimuli were acetic acid and hydrochloric acid. Each compound was used at four quarterlog-step concentrations: acetic acid, moles/liter: $0.18\left(\mathrm{~A}_{1}\right), 0.10\left(\mathrm{~A}_{2}\right)$, $0.056\left(\mathrm{~A}_{3}\right), 0.032\left(\mathrm{~A}_{4}\right)$; $\mathrm{HCl}$, moles/liter: $0.02\left(\mathrm{H}_{1}\right), 0.011\left(\mathrm{H}_{2}\right)$, $0.0063\left(\mathrm{H}_{3}\right), 0.0036\left(\mathrm{H}_{4}\right)$ (Table 1).

Nine mixtures of acetic acid and $\mathrm{HCl}$ were prepared by combination of concentrations 2,3 , and 4 . The highest concentrations $\left(A_{1}\right.$ and $\left.H_{1}\right)$ were used to ensure that an increase of sourness intensity as a result of mixing would not be obscured by a ceiling effect.

Self-adaptation was measured for all four concentrations of $\mathrm{HCl}$ and acetic acid and for the nine mixtures. Cross-adaptation was measured for the nine mixtures after adaptation to both acetic acid and $\mathrm{HCl}$. One of the mixture compounds was used as the adapting stimulus (e.g., adapting stimulus $\mathrm{A}_{2} \rightarrow$ test stimulus $\mathrm{A}_{2} \mathrm{H}_{3}$ ). Distilled water was used as the adapting stimulus for acetic acid, $\mathrm{HCl}$, and each of the nine mixtures.

\section{Apparatus and Procedure}

The filter paper method, derived from Gent and McBurney (1978) and modified for cross-adaptation experiments (Ganzevles \& Kroeze, $1987 \mathrm{~b}$ ), was used.

Before each trial, the subject rinsed his or her tongue thoroughly with distilled water and dried it with filter paper. The subject was instructed to extend the tip of the relaxed tongue about $2.5 \mathrm{~cm}$ between closed lips and to keep it that way during the whole trial. In this way, no interaction of saliva with the stimulus occurred. A square piece of Whatman (No. 91) filter paper $(18 \times 18 \mathrm{~mm})$ with a circular hole (11-mm diam) in the middle was soaked in a CMC solution $(0.5 \% \mathrm{w} / \mathrm{w}$, carboxy-methyl cellulose in water), after which it was placed on the extended tongue by means of Teflon-coated forceps. Then a circular piece of filter paper (Whatman 91, 11$\mathrm{mm}$ diam), soaked in one of the stimulus solutions, was placed in the hole of the square paper.

The subjects were instructed to pay attention to sourness only and to ignore any other taste quality. They estimated the sourness of the stimulus and wrote the estimate down immediately afterwards.

Table 1

Stimulus Solutions of $\mathrm{HCl}$, Acetic Acid, and Mixtures

\begin{tabular}{|c|c|c|c|c|}
\hline \multirow[b]{2}{*}{ Compound } & \multicolumn{3}{|c|}{ Concentration } & \multirow[b]{2}{*}{ pH } \\
\hline & $\mathbf{M} /$ liter & $\mathrm{H}^{+}{ }_{\mathrm{H}} /$ liter* & $\mathrm{H}^{+} \mathrm{A} /$ liter $\dagger$ & \\
\hline \multicolumn{5}{|c|}{ Hydrochloric Acid } \\
\hline $\begin{array}{l}\mathrm{H}_{1} \\
\mathrm{H}_{2} \\
\mathrm{H}_{3} \\
\mathrm{H}_{4}\end{array}$ & $\begin{array}{l}0.02 \\
0.011 \\
0.0063 \\
0.0036\end{array}$ & $\begin{array}{l}0.02 \\
0.011 \\
0.0063 \\
0.0036\end{array}$ & $\begin{array}{l}0 \\
0 \\
0 \\
0\end{array}$ & $\begin{array}{l}1.70 \\
1.95 \\
2.20 \\
2.45\end{array}$ \\
\hline \multicolumn{5}{|c|}{ Acetic Acid } \\
\hline $\begin{array}{l}\mathbf{A}_{1} \\
\mathbf{A}_{2} \\
\mathrm{~A}_{3} \\
\mathrm{~A}_{4}\end{array}$ & $\begin{array}{l}0.18 \\
0.10 \\
0.056 \\
0.032\end{array}$ & $\begin{array}{l}0 \\
0 \\
0 \\
0\end{array}$ & $\begin{array}{l}0.00177 \\
0.00131 \\
0.00098 \\
0.00074\end{array}$ & $\begin{array}{l}2.75 \\
2.88 \\
3.01 \\
3.13\end{array}$ \\
\hline \multicolumn{5}{|c|}{ Mixtures } \\
\hline $\begin{array}{l}\mathrm{A}_{2} \mathrm{H}_{2} \\
\mathrm{~A}_{3} \mathrm{H}_{2} \\
\mathrm{~A}_{4} \mathrm{H}_{2} \\
\mathrm{~A}_{2} \mathrm{H}_{3} \\
\mathrm{~A}_{3} \mathrm{H}_{3} \\
\mathrm{~A}_{4} \mathrm{H}_{3} \\
\mathrm{~A}_{2} \mathrm{H}_{4} \\
\mathrm{~A}_{3} \mathrm{H}_{4} \\
\mathrm{~A}_{4} \mathrm{H}_{4}\end{array}$ & $\begin{array}{l}\mathrm{H}_{2}+\mathrm{A}_{2} \\
\mathrm{H}_{2}+\mathrm{A}_{3} \\
\mathrm{H}_{2}+\mathrm{A}_{4} \\
\mathrm{H}_{3}+\mathrm{A}_{2} \\
\mathrm{H}_{3}+\mathrm{A}_{3} \\
\mathrm{H}_{3}+\mathrm{A}_{4} \\
\mathrm{H}_{4}+\mathrm{A}_{2} \\
\mathrm{H}_{4}+\mathrm{A}_{3} \\
\mathrm{H}_{4}+\mathrm{A}_{4}\end{array}$ & $\begin{array}{l}0.011 \\
0.011 \\
0.011 \\
0.0063 \\
0.0063 \\
0.0063 \\
0.0036 \\
0.0036 \\
0.0036 \\
\end{array}$ & $\begin{array}{l}0.000150 \\
0.000087 \\
0.000049 \\
0.000266 \\
0.000150 \\
0.000087 \\
0.000436 \\
0.000256 \\
0.000015\end{array}$ & $\begin{array}{l}1.94 \\
1.95 \\
1.95 \\
2.18 \\
2.19 \\
2.19 \\
2.41 \\
2.42 \\
2.43 \\
\end{array}$ \\
\hline
\end{tabular}

${ }^{*} \mathrm{H}^{+} \mathrm{H}=\mathrm{H}^{+}$concentration of $\mathrm{HCl} . \quad+\mathrm{H}^{+}{ }_{\mathrm{A}}=\mathrm{H}^{+}$concentration of acetic acid. 
The subjects reestimated the same stimulus five times, at the signal of a $50-\mathrm{dB} 1000-\mathrm{Hz}$ tone, at intervals of $15 \mathrm{sec}$. After $75 \mathrm{sec}$ (total adaptation time), the circular filter paper was removed by means of a circular glass filter (10-mm diam) that was connected to a vacuum installation (effective vacuum pressure on the filter was $5.3 \mathrm{~N} / \mathrm{m}^{2}$ ) and the test stimulus was placed in the hole of the square paper. The subjects were instructed to estimate the sourness of the test stimulus as soon as possible after the test paper was placed. After the subjects had estimated the sourness of the test stimulus, the stimulus and the square paper were removed. Rinsing with distilled water completed the trial. The intertrial interval was $50 \mathrm{sec}$. The same procedure was observed for all trials.

\section{Sessions and trials}

The nine mixtures and the four concentrations of $\mathrm{HCl}$ and of acetic acid were used in self-adaptation trials and after adaptation to distilled water. In addition to these 34 trials, there were 18 crossadaptation trials. Thus, the different trials totaled 52. Acetic acid and $\mathrm{HCl}$ served as adapting stimuli in the cross-adaptation trials. The nine mixtures served as test stimuli. The order of the 52 trials was randomized. The 52 trials were presented in two sessions of 26 trials each, one session a day on 2 consecutive days. Each of the 52 trials was replicated four times. This made for a total of eight sessions per subject.

\section{RESULTS}

Medians were calculated from the four individual replications of each trial. Since the subjects used modulus-free magnitude estimation, these medians were normalized to a common modulus in the following way. The medians of the first estimates in the adaptation course $\left(I_{0}\right)$ were used to calculate the individual means and a group mean for the 10 subjects. Subsequently, all medians were multiplied by the ratio of group mean and individual mean per subject. Rescaling in this way converts subjects to a common mean, while the scale properties are unaffected.

Table 2

Decay Constants $(\tau)$ and Coefficients of Fit $(r)$ of Adaptation Time Course

\begin{tabular}{ccc}
\hline \multicolumn{1}{c}{ Compound } & $\tau$ & $r$ \\
\hline Acetic Acid & & \\
$\mathrm{A}_{1}$ & 84.8 & 0.996 \\
$\mathrm{~A}_{2}$ & 67.3 & 0.998 \\
$\mathrm{~A}_{3}$ & 64.4 & 0.999 \\
$\mathrm{~A}_{4}$ & 52.0 & 0.995 \\
Hydrochloric Acid & & \\
$\mathrm{H}_{1}$ & 58.2 & 0.989 \\
$\mathrm{H}_{2}$ & 37.8 & 0.973 \\
$\mathrm{H}_{3}$ & 34.0 & 0.976 \\
$\mathrm{H}_{4}$ & 7.5 & 0.906 \\
$\mathrm{Mixtures}_{3}$ & & \\
$\mathrm{~A}_{2} \mathrm{H}_{2}$ & 80.3 & 0.991 \\
$\mathrm{~A}_{3} \mathrm{H}_{2}$ & 80.7 & 0.999 \\
$\mathrm{~A}_{4} \mathrm{H}_{2}$ & 71.0 & 0.998 \\
$\mathrm{~A}_{2} \mathrm{H}_{3}$ & 88.2 & 0.999 \\
$\mathrm{~A}_{3} \mathrm{H}_{3}$ & 76.3 & 0.995 \\
$\mathrm{~A}_{4} \mathrm{H}_{3}$ & 61.2 & 0.996 \\
$\mathrm{~A}_{2} \mathrm{H}_{4}$ & 71.2 & 0.995 \\
$\mathrm{~A}_{3} \mathrm{H}_{4}$ & 65.7 & 0.993 \\
$\mathrm{~A}_{4} \mathrm{H}_{4}$ & 52.7 & 0.996 \\
\hline
\end{tabular}

Decay constants were calculated from the equation $Y=A \cdot e^{-x / \tau}$, where $Y=$ perceived sourness and $x=$ time in seconds. The correlation coefficient $r$ relates $\log y$ and $x$.
Table 3

Parameters of the Psychophysical Function $I=k \cdot C^{n}$

\begin{tabular}{|c|c|c|c|c|c|c|}
\hline \multirow[b]{2}{*}{ Compound } & \multicolumn{2}{|c|}{$I_{0}$} & \multirow{2}{*}{$\begin{array}{c}\text { fit } \\
r\end{array}$} & \multicolumn{2}{|c|}{$I_{w}$} & \multirow{2}{*}{$\begin{array}{c}\text { fit } \\
r\end{array}$} \\
\hline & $n$ & $\log k$ & & $n$ & $\log k$ & \\
\hline $\begin{array}{c}\text { Acetic Acid } \\
1,2,3,4\end{array}$ & 0.418 & 1.35 & 0.996 & 0.357 & 1.37 & 0.902 \\
\hline $\begin{array}{l}\mathrm{HCl} \\
\quad 1,2,3,4 \\
1,2,3\end{array}$ & $\begin{array}{l}1.068 \\
0.723\end{array}$ & $\begin{array}{l}2.60 \\
1.96\end{array}$ & $\begin{array}{l}0.966 \\
0.999\end{array}$ & $\begin{array}{l}0.983 \\
0.665\end{array}$ & $\begin{array}{l}2.56 \\
1.97\end{array}$ & $\begin{array}{l}0.966 \\
1.000\end{array}$ \\
\hline $\begin{array}{l}\text { Mixtures* } \\
\mathbf{A}_{\mathbf{2 , 3}, \mathbf{4}} / \mathbf{H}_{\mathbf{2}, \mathbf{3}, \mathbf{4}}\end{array}$ & 0.444 & 1.40 & 0.978 & 0.325 & 1.34 & 0.928 \\
\hline $\begin{array}{l}\text { Mixtures } \dagger \\
\mathrm{A}_{2,3,4} / \mathrm{H}_{2,3,4}\end{array}$ & 0.096 & 1.08 & 0.230 & -0.015 & 0.98 & -0.047 \\
\hline
\end{tabular}

Note $-I_{0}=$ intensity estimated with unadapted tongue, $I_{w}=$ intensity estimated after adaptation to water. ${ }^{*}$ Calculated on total molar concentration. $\quad$ Calculated on total $\mathrm{H}^{+}$concentration.

A decay function $\left(Y=A \cdot e^{-x \prime}\right)$ was fitted to the mean results of the adaptation time course. The decay constants $(\tau)$ and the coefficients of fit $\left(r_{\log y, x}\right)$ are given in Table 2 . Two separate psychophysical functions $\left(I=k \cdot C^{n}\right)$ were calculated-one based on the intensity estimates with unadapted tongue $\left(I_{0}\right)$ and the other based on the estimates of the test stimuli after adaptation to water $\left(I_{w}\right)$ (Table 3 ).

With the lowest concentration of $\mathrm{HCl}\left(\mathrm{H}_{4}\right)$, half of the subjects produced estimates of zero. Therefore, the psychophysical functions for $\mathrm{HCl}$ were also calculated using the concentrations $1,2,3$.

The exponent $(n)$ of the acetic acid function agrees with the exponents found for the mixtures calculated on total molar concentration. However, the exponents obtained with $\mathrm{HCl}$ are much higher than those obtained for mixtures calculated on $\mathrm{H}^{+}$. This means that $\mathrm{HCl}$ contributes relatively little to the sourness of the mixtures. Although the consistency of the data and the fits observed with the estimates after adaptation to distilled water $\left(I_{w}\right)$ are somewhat lower, they permit the same conclusion.

The results of self-adaptation as measured with the test stimuli of acetic acid and $\mathrm{HCl}$ are shown in Figure 1. A decrease of acetic acid sourness was seen after adaptation to acetic acid $\left(A_{1}-52 \%, A_{2}-31 \%, A_{3}-17 \%, A_{4}-\right.$ $33 \%$ with respect to the time course range). No sourness decrease was observed in the case of $\mathrm{HCl}$. Figure 2 represents self-adaptation of the nine mixtures $\left(\mathrm{A}_{2} \mathrm{H}_{2}-\right.$ $56 \%, \mathrm{~A}_{3} \mathrm{H}_{2}-43 \%, \mathrm{~A}_{4} \mathrm{H}_{2}-45 \%, \mathrm{~A}_{2} \mathrm{H}_{3}-51 \%, \mathrm{~A}_{3} \mathrm{H}_{3}-$ $53 \%, \mathrm{~A}_{4} \mathrm{H}_{3}-39 \%, \mathrm{~A}_{2} \mathrm{H}_{4}-41 \%, \mathrm{~A}_{3} \mathrm{H}_{4}-46 \%, \mathrm{~A}_{4} \mathrm{H}_{4}-$ $38 \%$ with respect to the time course ranges).

In all cases-acetic acid, mixtures, and $\mathrm{HCl}$-perceived intensity increased after adaptation to distilled water relative to the intensities estimated with the unadapted tongue (in Figures 1 and 2, the perceived intensity at time zero, $I_{0}$ of the time course can be compared with the test stimulus after adaptation to water, $I_{w}$ ). In the case of $\mathrm{HCl}$, this increase is identical to the increase observed with selfadaptation (Figure 1, compare the test stimuli $\mathrm{H}_{n}$ and $\mathrm{H}_{\mathrm{nw}}$ ).

Figure 3 shows the perceived sourness of acetic acid and the mixtures with identical acetic acid concentration: after adaptation to distilled water (W), estimated with un- 

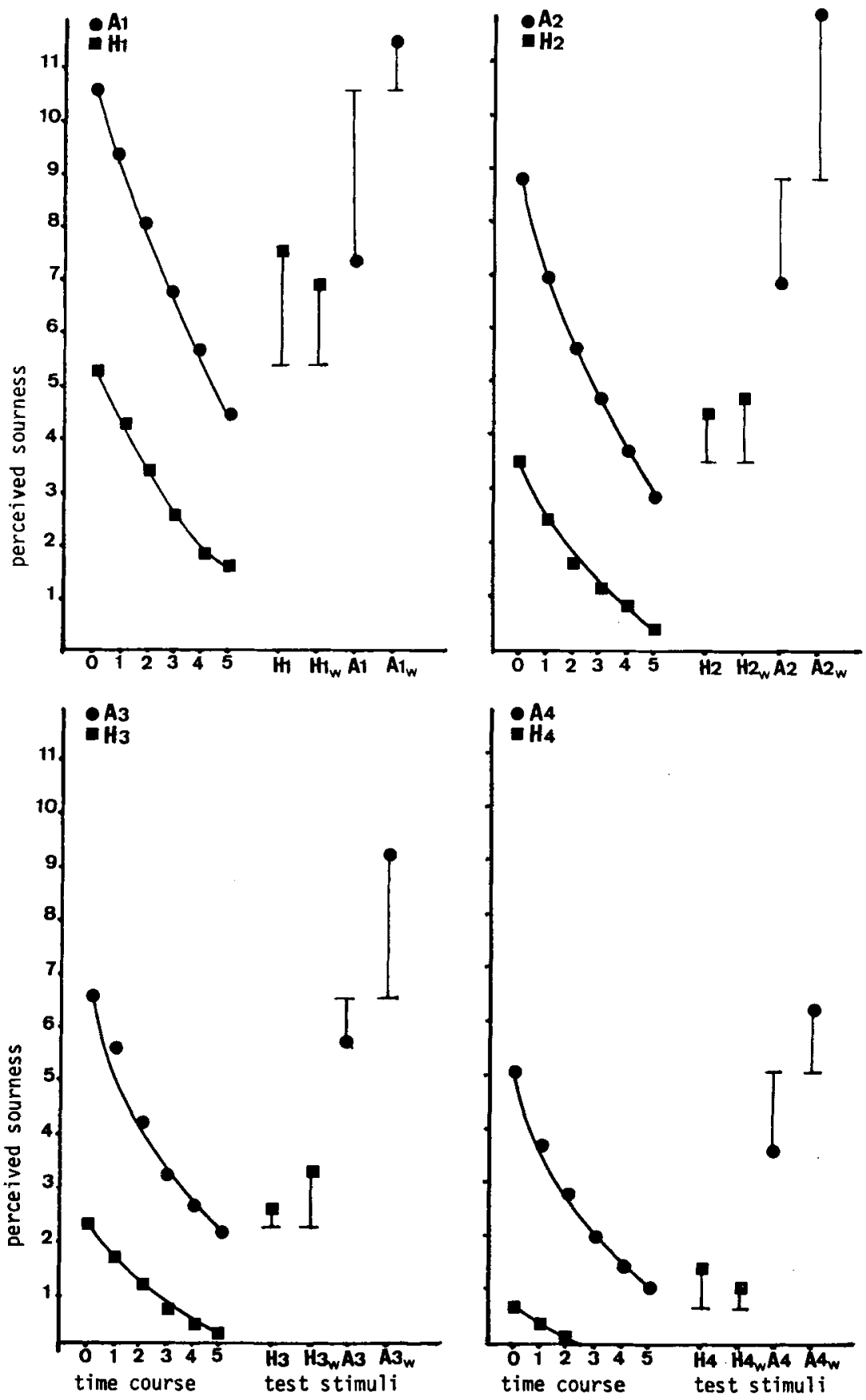

Figure 1. Perceived sourness of four concentrations of acetic acid and HCl during adaptation, and of test stimuli after adaptation to itself and to distilled water. $\mathbf{A}=$ acetic acid, $\mathbf{H}$ $=$ HCl. The subscript numbers refer to the stimulus concentrations (Table 1). The subseript $W$ refers to test stimuli after adaptation to distilled water.

adapted tongue (U), after self-adaptation (S), after adaptation to acetic acid (A), and to $\mathrm{HCl}(\mathrm{H})$. A multivariate analysis of variance (Finn, 1976)-adaptation condition $(\mathrm{W}, \mathrm{U}, \mathrm{S}) \times$ concentration $(2,3,4) \times$ compound (acetic acid, 3 mixtures)-showed condition $[F(2,8)=23.15$, $p<.01]$ and concentration $[F(2,8)=16.31, p<.01]$ to be significant. Compound $[F(3,7)=0.72]$ was not sig- nificant. Condition $\times$ concentration $[F(4,6)=10.18$, $p<.01]$ was the only significant interaction.

This means that there is no difference between acetic acid (A) and the sourness of mixtures with the same acetic acid concentration within the conditions of no adaptation (U), water adaptation (W), and self-adaptation (S). The effect of adaptation to acetic acid on the sourness of the 

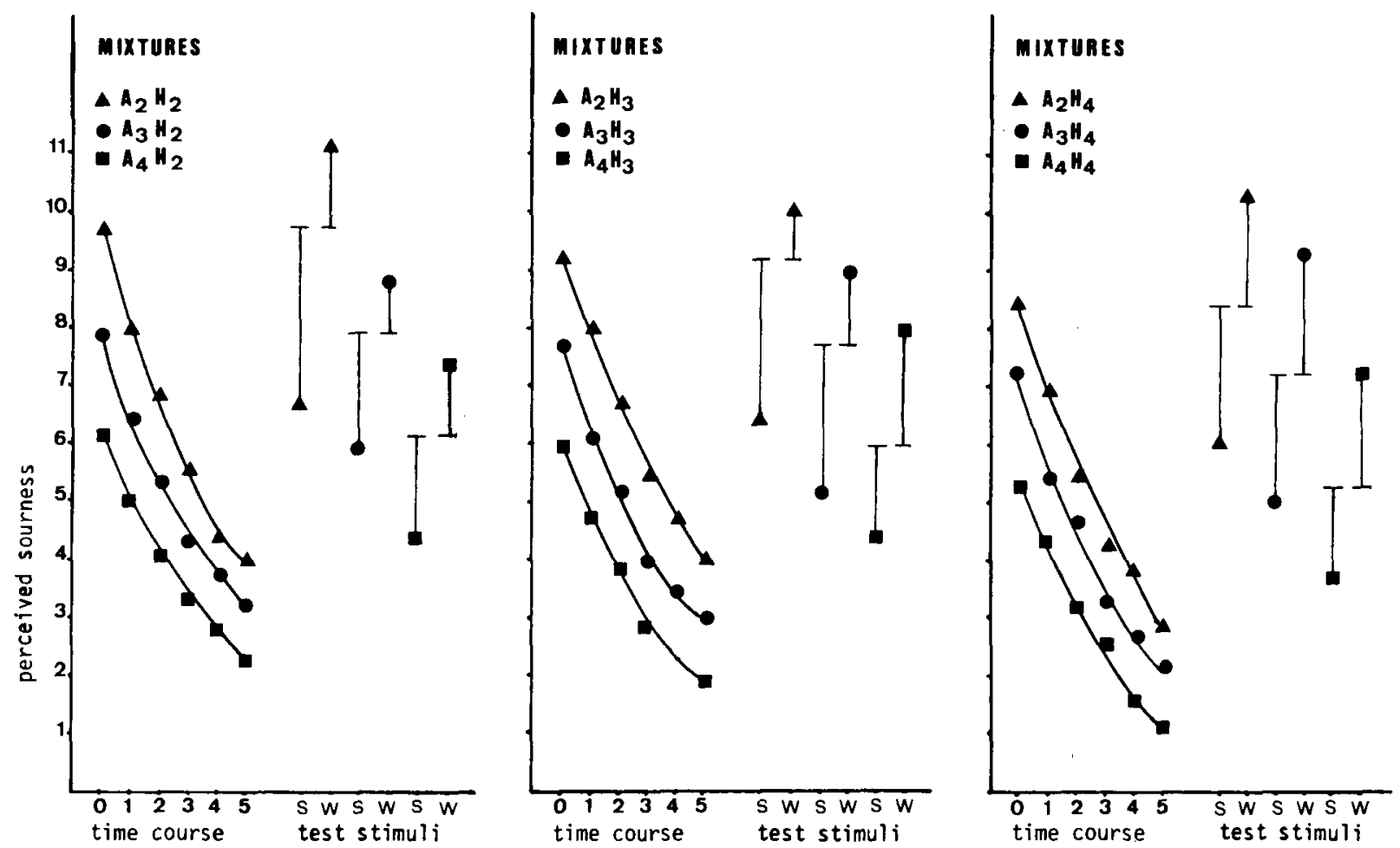

Figure 2. Perceived sourness of nine acetic acid (A)/HCl (H) mixtures during adaptation. Each mixture was tested after adaptation to itself (S) and after adaptation to distilled water (W).

mixtures did not differ from the effect of self-adaptation of acetic acid or from the mixtures (Figure 3, conditions $\mathrm{S}$ and $\mathrm{A})$. An analysis of variance for repeated measures (Ferguson, 1976)-compound (7) $\times$ concentration (3) showed concentration $[F(2,18)=34.48, p<.001]$ to be significant. Compound $[F(6,54)=1.265]$ and the compound $\times$ concentration interaction $[F(12,108)=0.0608]$ were not significant.

\section{DISCUSSION}

\section{Combination of Sourness from Different Sources}

Strong acids like $\mathrm{HCl}$ are completely dissociated. So one may assume that $\mathrm{HCl}$ sourness is identical to the sourness elicited by $\mathrm{H}^{+}$ions. The dissociation of weak acids (e.g., acetic acid) is incomplete. This means that in aqueous solutions the $\mathrm{H}^{+}$concentration is much lower than the molar concentration. The perceived sourness of weak acids, however, is larger than predicted by the $\mathrm{H}^{+}$concentration, or $\mathrm{pH}$.

Either of two titration-like processes may explain this discrepancy: (1) A two-step reaction, in which first the dissociation of weak acids is catalyzed and then sourness is elicited by the freed $\mathrm{H}^{+}$ions in the same way as with $\mathrm{HCl}$. In such a process, the $\mathrm{H}^{+}$ion exclusively is the sourness agent. In that case, the sourness of acetic acid depends on the molar concentration and on the degree of the catalyzed dissociation. (2) A bonding reaction of un- dissociated acid in which the functional group $(-\mathrm{COOH})$ plays a major role. Such a process may be independent of a process by which $\mathrm{H}^{+}$elicits sourness. Suppression of the $\mathrm{pH}$ in weak acids by buffering with their sodium salts has no effect on perceived sourness (Beidler, 1967; Ganzevles \& Kroeze, 1987c). These findings are in line with both processes. In both processes, the perceived sourness is independent of the measured $\mathrm{pH}$.

In Process 1, addition of $\mathrm{HCl}$ and acetic acid sourness may be expected because both compounds have a common sourness agent. In our mixtures, because of suppression of the acetic acid dissociation by $\mathrm{HCl}$, the sourness elicited by acetic acid must be the result of activity of undissociated acid (HA). $\mathrm{H}^{+}(\mathrm{HCl})$ sourness and $\mathrm{HA}$ (acetic acid) sourness do not combine to a higher perceived sourness. Thus, the results do not favor Process 1 . This may also mean that the sourness of weak carboxylic acids is not a combined effect of $\mathrm{H}^{+}$and $\mathrm{HA}$.

The present results seem to contrast with findings of Moskowitz (1974) and Curtis et al. (1984). They reported, respectively, synergism and partial additivity of citric acid sourness and $\mathrm{HCl}$ sourness. The dissociation degree of citric acid is larger than that of acetic acid. But if one uses $\mathrm{HCl}$ to establish the sourness of a given amount of $\mathrm{H}^{+}$ ions, the sourness of citric acid cannot be due entirely to $\mathrm{H}^{+}$ions. Furthermore, in mixtures with $\mathrm{HCl}$, the dissociation of citric acid is suppressed. It is likely that the physicochemical properties of carboxylic acids in aque- 

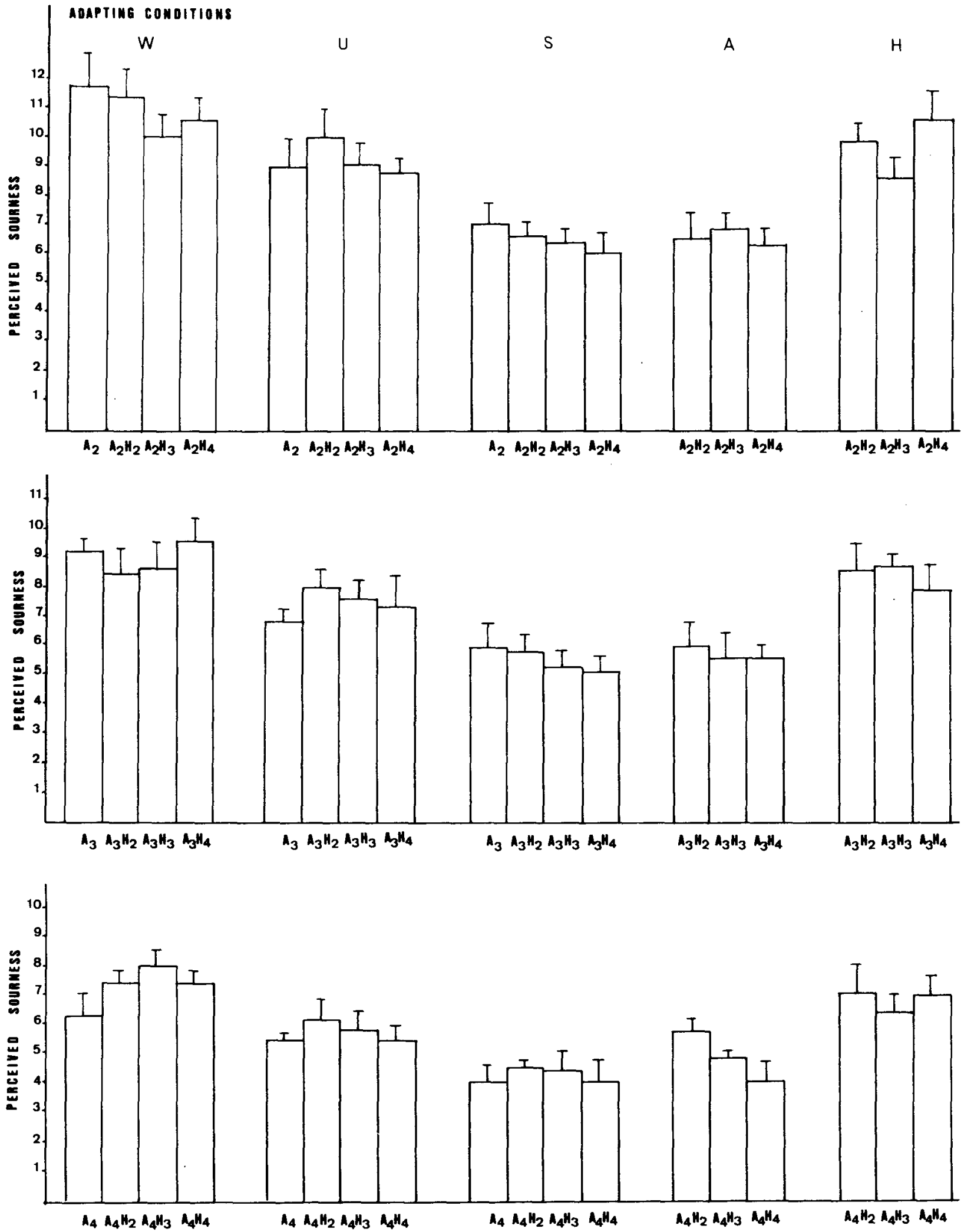

Figure 3. Perceived sourness of acetic acid $\left(A_{2}\right.$ upper panel, $A_{3}$ middle panel, $A_{4}$ lower panel) and of acetic acid/HCl mixtures. The sourness was measured (1) after adaptation to distilled water $(W),(2)$ with unadapted tongue (U), (3) after adaptation to itself (S), (4) after adaptation to acetic acid with the same molar concentration as the acetic acid component in the mixture (A), and (5) after adaptation to $\mathrm{HCl}$ with the same molar concentration as the $\mathrm{HCl}$ component in the mixture (H). 
ous solutions have an effect on the acid-taste epithelium interaction. It may be speculated that citric acid, which is more polar than acetic acid, has an effect on the tastecell membrane which enhances the effect of $\mathrm{H}^{+}$. However, Moskowitz (1974) and also Curtis et al. (1984) obtained their results with a sip-and-spit procedure in which saliva interaction may play an important role. This difference in methods complicates proper comparison of their studies with ours.

\section{The Effect of pH on Adaptation}

In earlier studies (Ganzevles \& Kroeze, 1987b), it was found that self-adaptation measured with a test stimulus was lower for carboxylic acids than for nonacidic compounds. Further research revealed that no self-adaptation could be observed in the case of $\mathrm{HCl}$ and that the sourness of $\mathrm{H}^{+}$and of undissociated acid (HA) probably reflected different receptor processes (Ganzevles \& Kroeze, 1987a). A possible explanation for the low selfadaptation of carboxylic acids was that the activity of $\mathrm{H}^{+}$ (which is not adapted) counteracted the sourness decrease resulting from adaptation to undissociated acid (Ganzevles \& Kroeze, 1987c). On the basis of this assumption, it was expected that increasing $\mathrm{H}^{+}$concentration by adding $\mathrm{HCl}$ to a carboxylic acid would result in a decrease of selfadaptation. However, the results of the present experiment show that this is not the case. Self-adaptation of the mixtures does not differ from the self-adaptation observed with the corresponding acetic acid concentration (Figure 3). These results agree with the finding that $\mathrm{HCl}-$ sourness and acetic acid-sourness do not combine to a higher perceived sourness.

Relative to the sourness estimated with the unadapted tongue $\left(I_{0}\right)$, the sourness increased after adaptation to distilled water $\left(I_{\mathrm{w}}\right)$. It was suggested by Ganzevles and Kroeze (1987c) that some saliva remains on the surface of the tongue despite the distilled water rinse. This saliva partly neutralizes the acid stimuli, but during adaptation to water it is extracted and removed when the stimuli are changed. The amount of saliva involved depends on the effectiveness of the rinse. Thus, if saliva indeed neutralizes a part of the acid, the relative sourness increase after adaptation to distilled water, expressed as $\left(I_{w}-I_{0}\right) / I_{0}$, will become smaller with increasing acid concentration. Tested over the nine mixtures (Figure 2), the effect is significant: $r=-0.609, p<.05$, one-sided.

\section{Concluding Remarks}

On the basis of the different results observed between adaptation of $\mathrm{HCl}$ and carboxylic acids, Ganzevles and Kroeze $(1987 \mathrm{a}, 1987 \mathrm{c})$ suggested that in the case of the hydrogen ion and in the case of undissociated acid, different receptor processes are involved. The present results support this hypothesis. If no addition of taste intensity occurs with these two processes, it means that the neural information (labeled sour) also remains separated at a central level. This may suggest that sourness is not a taste primary as such (Erickson, 1982; Erickson \& Covey, 1980).

Thus, $\mathrm{HCl}$ and carboxylic acids cannot be used in taste research as mutual substituents or as model agents for the sourness quality. The discrepancy between the present results and those of Moskowitz (1974) and of Curtis et al. (1984) suggests that the chemical interaction between carboxylic acids and taste receptors varies with the physicochemical properties of the acids. More information about the sourness of mixtures of $\mathrm{HCl}$ with different types of carboxylic acids is needed to answer the question of whether or not there is an addition of sourness originating from different sources.

\section{REFERENCES}

BeAtTy, R. M., \& CraGg, L. H. (1935). The sourness of acids. Journal of the American Chemical Society, 57, 2347-2352.

BeETs, M. G. J. (1978). The sour and salty modalities. In M. G. J. Beets (Ed.), Structure activity relationships in human chemoreception (pp. 348-356). London: Applied Science Publishers.

BeIDLER, L. M. (1967). Anion influences on taste receptor response. In T. Hayashi (Ed.), Olfaction and taste II (pp. 509-535). New York: Pergamon Press.

Chauncey, H. H., Feller, R. P., \& Shannon, I. L. (1967). Measurement of human gustatory perception using parotid gland secretion rate. In T. Hayashi (Ed.), Olfaction and taste II (pp. 265-287). New York: Pergamon Press.

CrouzIER, W. J. (1916). The taste of acids. Journal of Comparative Neurology, 26, 453-462.

Curtis, D. W., Stevens, D. A., \& Lawless, H. T. (1984). Perceived intensity of the taste of sugar and acid mixtures. Chemical Senses, 9, $107-120$.

ERICKSON, R. P. (1982). Studies on the perception of taste: Do primaries exist? Physiology \& Behavior, 28, 57-62.

Erickson, R. P., \& Covey, E. (1980). On the singularity of taste sensations: What is a taste primary? Physiology \& Behavior, 25, 527-533.

FERGUSON, G. A. (1976). Statistical analysis in psychology and education. Tokyo: McGraw-Hill, Kogakusha.

FINN, J. D. (1976). Multivariance. Version V, release 3 [A Fortran IV program]. Chicago: National Educational Resources.

FriJters, J. E. R., \& OUdE OPhuis, P. A. M. (1983). The construction and prediction of psychophysical power-functions for the sweetness of equiratio sugar mixtures. Perception, 12, 753-767.

Ganzevles, P. G. J., \& Kroeze, J. H. A. (1987a). Acid sourness, the effect on taste intensity of adaptation and cross-adaptation to common ions. Physiology \& Behavior, 40, 641-646.

Ganzevles, P. G. J., Kroeze, J. H. A. (1987b). Cross-adaptation in taste measured with a filter paper method. Chemical Senses, 12, 341-353.

Ganzevles, P. G. J., Kroeze, J. H. A. (1987c). The sour taste of acids. The hydrogen ion and the undissociated acid as sour agents. Chemical Senses, 12, 563-576.

GARDNER, R. J. (1980). Lipid solubility and the sourness of acids: Implications for models of the acid taste receptor. Chemical Senses \& Flavour, 5, 185-194.

GeNT, J. F., \& MCBuRney, D. H. (1978). Time course of gustatory adaptation. Perception \& Psychophysics, 23, 171-175.

HARVEY, R. B. (1920). The relation between the total acidity, the concentration of the hydrogen ion and the taste of acid solutions. Journal of the American Chemical Society, 42, 712-714.

KenRICK, F. B. (1931). The sour taste of acids. Transactions of the Royal Society of Canada, 25, 227.

LAWLESS, H. T. (1979). Evidence for neural inhibition in bittersweet taste mixtures. Journal of Comparative \& Physiological Psychology, 93, 538-547. 
LAWLESS, H. T. (1982). Paradoxical adaptation to taste mixtures. Physiology \& Behavior, 25, 149-152.

MAKHLOAF, G. M., \& BLum, A. L. (1972). Kinetics of the taste response to chemical stimulation. A theory of acid taste in man. Gasterentology, 63, 67-75.

Moskowitz, H. R. (1974). Sourness of acid mixtures. Journal of Experimental Psychology, 102, 640-647.

Norris, N. B., Noble, A. C., \& PANGBorn, R. M. (1984). Human saliva and taste responses to acids varying in anions, titrable acidity and pH. Physiology \& Behavior, 32, 237-244.
PILNIK, W. (1964). Über den sauren Geschmack von Fruchtsäuren. Flüssiges Obst, 33, 316-318.

Stevens, S. S. (1975). Psychophysics: Introduction to its perceptual, neural and social prospects. New York: Wiley.

TAYLOR, N. W., FARTHING, F. R., \& BERMAN, R. (1930). Quantitative measurements on the acid taste and their bearing on the nature of the nerve receptor. Protoplasma, 10, 84-97.

(Manuscript received March 10, 1987; revision accepted for publication August 20, 1987.) 